\title{
$\mathrm{CO}_{2}$ 모형 경주차를 이용한 차량 공기역학의 공학설계 사례연구
}

\author{
장현탁 $1^{*}$ \\ ${ }^{1}$ 아주자동차대학 자동차 계열
}

\section{A Case Study in Engineering Design of Vehicle Aerodynamics Course by $\mathrm{CO}_{2}$ Model Dragster}

\author{
Hyun-Tak Jang ${ }^{1^{*}}$ \\ ${ }^{1}$ Division of Automotive, Ajou Motor College
}

\begin{abstract}
요 약 현재 전문대학의 자동차 학과에서 제공되는 교육이 이론교육에 치우쳐 실제 산업현장에서 적용과 응용능력 에 문제점이 있다고 지적이 있어왔다. 이 연구는 창의적인 자동차설계 능력을 배양하기 위하여 A 대학의 모터스포츠 전공에서 차량 공기역학에 $\mathrm{CO}_{2}$ 경주차 설계를 수행한 성공적인 수업내용의 사례를 살펴본다. $\mathrm{CO}_{2}$ 모형 경주차 제작 규정, 제작 과정, 성능 시험 등시 제시 되었으며, $\mathrm{CO}_{2}$ 모형 경주차의 속도 및 항력이 측정되었다. 공학설계가 학생들 의 학습에 미친 영향을 알아보기 위하여 2008년 봄 학기에 설문조사를 실시하였다. 설문조사에 따른면 학생들의 공 학설계 능력과 만족도에 높은 가치를 부여하였다.
\end{abstract}

\begin{abstract}
Recently, there have been a number of voices from industry that automotive education at the college is too theoretical and so college graduates are lack of practical ability to apply the automotive idea to actual systems. In order to educate engineering students design qualities in creative problem solving, this paper reports the results of employing engineering design projects in a Motor sports course of at A College. This paper presents design creterion and manufacture process of $\mathrm{CO}_{2}$ model dragster, measures $\mathrm{CO}_{2}$ model dragster speed and aerodynamic drag. In order to investigate the impact of engineering design on student's learning, a survey was conducted in 2008 spring semester. According to the results of survey analyses, student's key competencies and satisfaction reports high values on engineering design projects.
\end{abstract}

Key Words : Engineering design, $\mathrm{CO}_{2}$ Model dragster, Vehicle aerodynamics, Aerodynamic drag, Aerodynamic drag coefficient, Wind tunnel.

\section{1. 서론}

\section{1 연구 필요성 및 필요성}

공학 설계는 학생들의 보다 나은 학습을 위하여 공학 의 커리큘럼에 소개되고 시도되어 왔다. 공학설계 활동을 통하여 재료, 규정, 경제적 요소, 제작 상의 특성, 안전 및 환경 문제 등이 서로 연관되어 있음을 학생들은 구체적 으로 이해하게 된다[1,5].

공학설계가 자동차 공학교육에서 강조되어야 하는 이 유는 여러 가지가 있다. 공학 설계는 창의성을 대변하고 있기 때문에 자동차를 전공한 학생이라면 하나의 자동차
부품설계에 수반되는 구성 요소 및 과정을 설계할 수 있 어야 한다. 이러한 이유로 자동차를 교육시키는 과정에서 부터 단순한 정비지식을 전수하는 차원이 아닌 보다 실 제적이고도 응용력을 가춘 사람이 되도록 교육과정의 설 계가 필요하다. 사실 학교를 졸업하면 산업현장에 근무하 게 되었을 때 필수적으로 갖추어야 할 능력이다.

두 번째 이유는 오늘날 자동차 공학의 문제 해결은 혼 자가 아닌 팀 단위로 이루어지기 때문이다. 실제 세계에 서 문제 상황이 한 두 사람의 힘으로 해결되는 경우보다 여러 사람이 참여하고 여러 분야의 전문지식이 통합하여 발휘되어야만 해결이 가능하기 때문이다. 공학설계 프로

"교신저자 : 장현탁(wslong@motor.ac.kr)

접수일 10 년 06 월 28 일 수정일 10 년 07 월 23 일 게재확정일 10 년 08 월 10 일 
젝트에서 팀 단위의 공동노력을 강조하는 현실적인 요구 에 부응하는 교수방법이다. 공학 설계 과정을 자동차 공 학교육의 프로젝트 활동을 통하여 통합하면 현실적인 제 한점들에 대한 높은 차원의 학습활동을 계획 할 수 있다. 이런 이유 때문에 자동차 분야의 교육에 공학설계 활동 을 통합하고 있다. 공학교육자에 의해 자동차 공학 수업 에 다양한 공학설계의 주제가 소개되고 시도되고 있다. 그러나 자동차 공학교육에서 공학설계의 중요성에 대한 인식에도 불구하고 공학설계의 교육과정에 대한 경험적 연구는 아직 그 수가 많지 않다.

$\mathrm{A}$ 대학 모터스포츠 전공의 2학년 수업에 차량 공기역 학 교과목에서 공학 설계의 사례로 " $\mathrm{CO}_{2}$ 모형 경주차의 설계-제작-시험-경주-보고를 기획하고 학생들이 팀별로 참여하도록 운영하였다. 본 논문은 A 대학의 모터스포츠 전공의 차량 공기역학 수업의 $\mathrm{CO}_{2}$ 모형 경주차 제작 규 정, 제작 과정, 성능시험을 제시하고, 경주차의 속도 및 항력을 측정한다. 그리고 학생들의 수업 개선 효과를 파 악하기 위하여 설문지를 개발하고, 분석결과를 토대로 공 학설계 능력 향상과 수업 만족도를 확인한다.

\section{2. 공학 설계 교육 방법과 과정}

\section{$2.1 \mathrm{CO}_{2}$ 모형 경주차 정의}

경주차의 과학적 원리를 잘 나타나도록 잘 구분되고 구성된 산업체 설계를 본 따서 경주차 공학을 습득하고 연마하도록 학생들에게 공학 설계 사례가 요구된다. 공학 설계의 예제로 $\mathrm{CO}_{2}$ 모형 경주차를 $\mathrm{CO}_{2}$ 카트리지에 압축 하여 충진 된 $\mathrm{CO}_{2}$ 가스가 빠르게 밖으로 분출되면서 추 진되는 $\mathrm{CO}_{2}$ 모형 경주차 설계를 목표로 한다. 학생들이 팀별로 가장 빠른 경주차를 모델링하고, 발사나무를 가공 하여 $1 / 20$ 축소된 $\mathrm{CO}_{2}$ 모형 경주차를 만들어 $20 \mathrm{~m}$ 트랙에 서 직선 가속 경주를 하여 자동차의 물리법칙을 이해하 는 수업이다[2].

\section{$2.2 \mathrm{CO}_{2}$ 모형 경주차 설계}

\subsection{1 $\mathrm{CO}_{2}$ 모형 경주차 설계 규정}

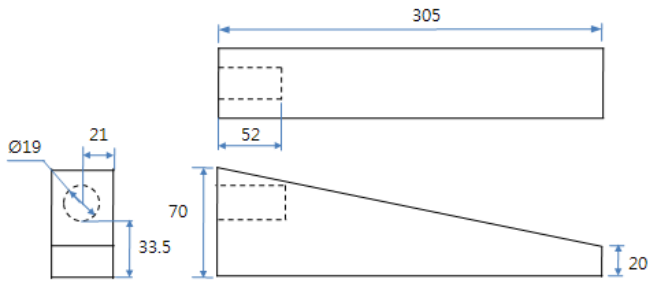

[그림 1] 발사우드 재료치수
- 바디 재료 치수

모형 경주차 바디는 모두 발사나무(balsa wood)를 사 용하여 전체를 하나로 제작해야 한다. 발사나무는 비중이 0.2 이하로 가볍고 부드러운 재료이다. 그림 1 은 발사 우 드의 재료의 기본 치수를 보여준다.

\section{- 본체 규정}

발사우드는 공작하기 쉬워 모형 자동차의 형체 재료로 널 리 사용된다. 바디 강화물, 플라스틱 덮게, 또는 날개와 같은 부가적인 장치를 바디에 덧붙여서는 안 된다. 즉 바디나 바 퀴 유리섬유 또는 포장 필름을 강화물로 사용할 수 없다.

$\mathrm{CO}_{2}$ 경주차을 설계 제작한 후의 그림 2 와 같은 치수 를 만족해야한다. 다음 표 1 은 $\mathrm{CO}_{2}$ 경주차 본체 규정을 최대 및 최소 치수를 정리한 표이다.
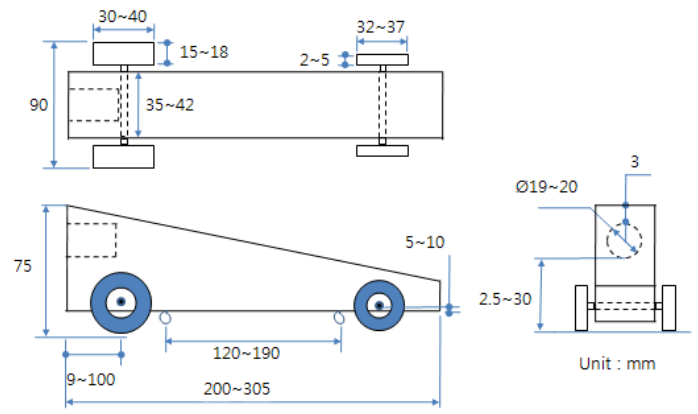

[그림 2] 본체규정

[표 1] 본체규정

\begin{tabular}{|c|c|c|}
\hline 바디 치수 & 최소 & 최대 \\
\hline 전장 & $200 \mathrm{~mm}$ & $305 \mathrm{~mm}$ \\
\hline 전고(바퀴포함) & - & $75 \mathrm{~mm}$ \\
\hline 차체 폭 & $35 \mathrm{~mm}$ & $42 \mathrm{~mm}$ \\
\hline 전폭 & - & $90 \mathrm{~mm}$ \\
\hline 무게 $\left(\mathrm{CO}_{2}\right.$ 제외 $)$ & $55 \mathrm{~g}$ 이상 & \\
\hline
\end{tabular}

- 차축 규정

바디에 앞, 뒤 차축(2개)이 설치되어야 하고 비닐튜브, 부싱, 윤활유 등 부품을 사용한다. 다음 표 2 는 $\mathrm{CO}_{2}$ 경주 차 차축 규정을 요약한 표이다.

[표 2] 차축규정

\begin{tabular}{|c|c|c|}
\hline 차축 치수 & 최소 & 최대 \\
\hline 축 높이 & $5 \mathrm{~mm}$ & $10 \mathrm{~mm}$ \\
\hline 뒤 바디 오버행 & $9 \mathrm{~mm}$ & $100 \mathrm{~mm}$ \\
\hline 윤거 & $105 \mathrm{~mm}$ & $270 \mathrm{~mm}$ \\
\hline
\end{tabular}


- 바퀴

차축에 총 4 개 바퀴가 장착되어 레이싱 트랙 지면에 접촉하고 회전하는 기능이 있어야한다. 팀들은 규정 내에 서 개성이 있는 바퀴를 플라스틱으로 만들 수 있다. 다음 표 3 는 $\mathrm{CO}_{2}$ 경주차 바퀴 규정을 요약한 표이다.

[표 3] 차축규정

\begin{tabular}{|c|c|c|}
\hline 바퀴 치수 & 최소 & 최대 \\
\hline 앞 바퀴 지름 & $32 \mathrm{~mm}$ & $37 \mathrm{~mm}$ \\
\hline 앞 바퀴 너비 & $2 \mathrm{~mm}$ & $5 \mathrm{~mm}$ \\
\hline 뒤 바퀴 지름 & $30 \mathrm{~mm}$ & $40 \mathrm{~mm}$ \\
\hline 뒤 바퀴 너비 & $15 \mathrm{~mm}$ & $18 \mathrm{~mm}$ \\
\hline
\end{tabular}

- 동력장치

$\mathrm{CO}_{2}$ 카트리지 구멍은 레이싱 트랙 지면과 평행하게 제작해야 한다. 경주 전에 $\mathrm{CO}_{2}$ 가 $60 \mathrm{bar}$ 압력으로 $8 \mathrm{~g}$ 충전 되어 있는 $\mathrm{CO}_{2}$ 카트리지를 제공한다. 다음 표 4 는 $\mathrm{CO}_{2}$ 경주차 동력장치 규정을 요약한 표이다.

[표 4] 동력 장치 규정

\begin{tabular}{|c|c|c|}
\hline 챔버 & 최대 & 최소 \\
\hline 챔버 깊이 & $50 \mathrm{~mm}$ & $52 \mathrm{~mm}$ \\
\hline 안전 벽 두께 & $3 \mathrm{~mm}$ & - \\
\hline 챔버 지름 & $19 \mathrm{~mm}$ & $20 \mathrm{~mm}$ \\
\hline 챔버 트랙 거리 & $22.5 \mathrm{~mm}$ & $30 \mathrm{~mm}$ \\
\hline
\end{tabular}

- 아이 스크루

두 개의 아이스크루 구멍을 통해서 트랙 선을 따라서 주행한다. 밑면 중심에 아이스크루가 앞과 뒤에 2 개의 장 착되어야 한다. 트랙 선이 빠져나가지 않게 아이스크루의 홀을 닫히게 만들어야 한다. 각 아이스크루는 트랙지면과 닿지 않게 만들어야 한다. 다음 표 5 는 $\mathrm{CO}_{2}$ 경주차 아이 스크루 규정을 요약한 표이다.

[표 5] 아이스크루 규정

\begin{tabular}{|c|c|c|}
\hline 아이 스크루 & 최소 & 최대 \\
\hline 지름 & $3 \mathrm{~mm}$ & $5 \mathrm{~mm}$ \\
\hline 거리 & $120 \mathrm{~mm}$ & $190 \mathrm{~mm}$ \\
\hline
\end{tabular}

\subsection{2 $\mathrm{CO}_{2}$ 모형 경주차 제작 과정}

우선 공학설계의 관점에서 설계란 무엇인가를 설명한 다. 예를 들면, "Form Follows Function" 오래된 격언의 설명을 통해, $\mathrm{CO}_{2}$ 경주차 디자인은 “고속 경주차의 기능 을 따르게 하라"라고 정의된다. 학생들이 서로 몸을 부딪 기며 팀별로 아이디어 스케치, 디자인스케치, 제작, 조립
등을 통하여 모형 경주차 제작을 경험하게 된다. 그림 3 은 $\mathrm{CO}_{2}$ 모형 경주차의 제작과정을 보여준다.

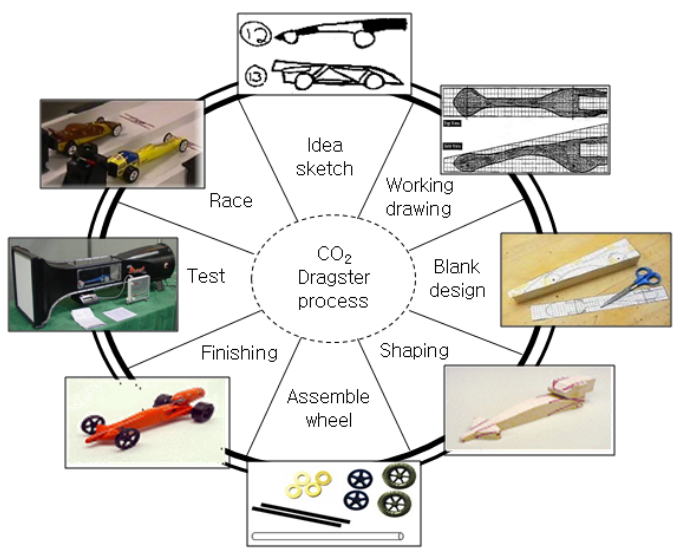

[그림 3] $\mathrm{CO}_{2}$ 모형 경주차의 제작과정

- 아이디어 스케치

규정에 제약을 받지 않고 가장 빠른 경주 차의 외관 형상을 디자인하기 위하여 새로운 아이디어 발상을 시도 하고 도전하는 자세가 필요하다. 그리고 가장 빠른 경주 차의 개발방향으로 독창적인 이미지를 간략하게 스케치 한다.

- 디자인 스케치

아이디어 스케치에서 묘사된 이미지를 치수 요건을 부 여하고 구체적인 외관 형상으로 정착해 나가는 기법이다. 아이디어 스케치에서 아이디어를 선택하여 디자인 스케 치를 작성한다. 자유로운 방향에서 보고 그려진 아이디어 스케치를 정면, 평면, 측면의 방향에서 본 스케치로 다시 만든다.

\section{- 작업도면}

작업 도면은 풀 사이즈로 모눈종이에 3각 투상법으로 작성하는데, $1 / 1$ 작업 도면의 풀사이즈 균형, 치수(최소, 최대) 규정 값을 확인하고 수정하여 생산 기술상의 여건 을 반영한다. 디자인한 $\mathrm{CO}_{2}$ 경주차 작업 도면은 소재 상 태의 발사나무에 부착하여 직접 수 가공으로 제작하기 위하여 템플릿으로 이용된다.

- 절단

템플릿은 $\mathrm{CAD}$ 를 사용하여 실척으로 출력한 후에 소 재인 발사나무 블록의 양쪽 면에 정면도, 평면도를 부착 한다. 먼저 톱을 사용하여 평면도의 템플릿 형상을 따라 이동하면서 절단한다. 다음은 각 조각들을 모아서 재조립 
하고 테이프로 고정한 후에 정면도의 템플릿 형상을 따 라 톱으로 절단한다. 절단 작업 후, 디자인한 $\mathrm{CO}_{2}$ 경주차 의 대략적인 형상이 완성된다. $3 / 16^{\prime \prime}$ 드릴을 사용하여 전 륜 축, 후륜 축의 구멍을 가공한다. 축의 구멍은 바디의 길이방향에 정밀하고 수직하게 제작한다.

- 바디 형상 제작

줄, 조각칼을 사용하여 수작업으로 곡면을 조금씩 깎 아 내면 바디 형상이 완성된다. 이제 연마지 $(100$, 220-grit)를 사용하여 다듬기 작업이 끝나면 발사 나무의 바디형상은 고운 표면으로 깨끗이 마무리 된다. 바디 형 상의 대칭성을 검사한다.

\section{- 도장}

$\mathrm{CO}_{2}$ 카트리지 챔버에 $5 / 8$ “지름의 보조 봉을 끼워 우 레탄 래커 또는 에폭시 페인트와 같은 칼라 페인트를 사 용하여 스프레이 또는 붓으로 페인트를 칠한다. 도장이 건조되기 까지 조립을 준비한다.

\section{- 최종조립}

최종 조립 부품으로는 2 개 축, 2 개 튜브 베어링, 4 개 바퀴, 4 개 와셔, 2 개 아이 스크루가 있다. 축의 길이는 양 쪽 바퀴의 조립치수를 포함하여 요구되는 길이로 절단한 다. 절단 시에 축의 굽힘이 없도록 주의한다. 각 차축 구 멍에 차축 베어링으로 사용되는 빨대를 끼운다. 조립 시 빨대의 외부표면과 축 구멍은 접착제를 사용하여 부착한 다. 차축 베어링인 빨대는 차폭보다 길지 않은 것이 좋다. 각각의 차축에 끼워서 전륜과 후륜을 단단히 고정한다. 동시에 4 개의 와셔를 바퀴 내부에 삽입한다. 조립된 바퀴 가 평면에서 부드럽고 자유롭게 회전 시험을 한다. 드래 그 경주 시 바퀴가 빠지지 않도록 조립한다. 아이 스크루 2 개를 규정에 맞게 바디 밑면의 중앙선에 조립한다.

\section{$2.3 \mathrm{CO}_{2}$ 모형 경주차 성능 시험}

\section{- 풍동 시험}

풍동이란 특정 물체를 정지한 상태에서 측정 장치에 설치하고 모형 경주차에 바람을 불어 그 물체에 작용하 는 공기역학적 특성을 예측할 수 있다. 풍동 시험으로 $\mathrm{CO}_{2}$ 모형 경주차의 항력계수 $\left(C_{D}\right)$ 측정을 수행하였다. 풍동의 작동 단면 치수는 폭이 $30 \mathrm{~cm}$, 높이 $30 \mathrm{~cm}$ 으로 작 지만 차량의 실물 크기의 $1 / 20$ 모형 경주차를 시험하기에 충분하고 바람의 속도는 $0 \sim 72 \mathrm{~km} / \mathrm{h}$ 까지 조절이 가 능하다. 그림 4는 항력 측정에 사용된 Open-return 형 소 형 풍동이다.

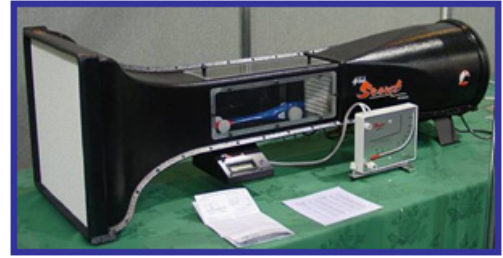

[그림 4] 소형 풍동

- 연기 터널

스모그 터널은 층류 유동과 난류 유동이 $\mathrm{CO}_{2}$ 모델 경 주차 표면 주위의 어디에서 발생하는지 직접 눈으로 확 인 할 수 있는 공기역학적 실험 장치이다. 그림 5 는 시험 에 사용한 연기 터널이다.

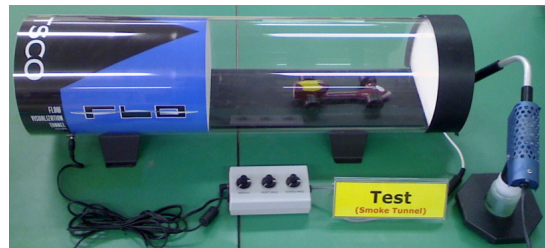

[그림 5] 연기 터널

- 차륜정렬 시험

그림 6은 해당 경주차를 테스트 램프 위에 올려놓고 자유 낙하시켜 직진 주행성을 시험한다. 차륜이 자동차의 중심선에 직각으로 조립되어 있지 않으면 직진 주행 중 에 옆 방향으로 쏠림이 발생한다. 주행한 거리와 중심선 에서 벗어난 거리를 측정하여 정밀성 \%는 다음 식으로 계산된다.

$$
p_{a}=100-\frac{D_{c}}{D_{t}} \times 100
$$

즉 바퀴가 올바르게 조립되지 않고 토우와 캠버가 있 는 경우에 주행 불안정성을 일으키게 된다.

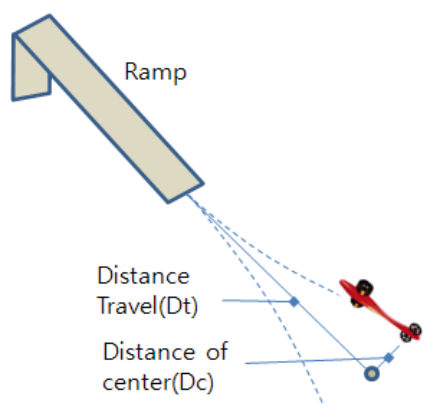

[그림 6] 램프 시험 


\section{- 휠 스핀 시험}

제작한 모형 경주차를 뒤집어 놓고 뒤 바퀴를 손가락 으로 회전시킨 후에 멈출 때 까지 스톱워치로 소요 시간 을 계측한다. 만약 모형 경주차바퀴가 불안정 하게 흔들 거리며 회전하면, 빠르게 감속하여 바퀴가 멈출 것이다. 그림 7은 휠 스핀 시험방법을 그림으로 보여준다.

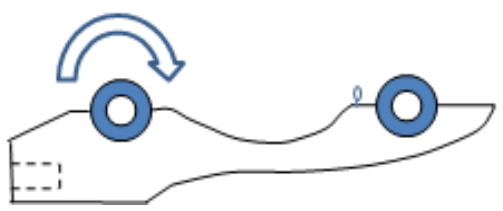

[그림 7] 휠 스핀 시험

- 무게 측정

전자저울을 이용하여 완성된 모형 경주차의 무게를 측 정한다.

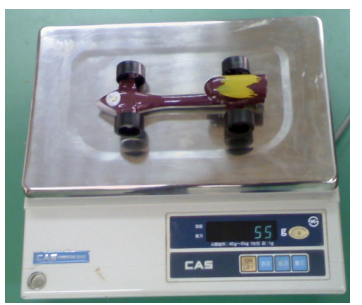

[그림 8] 무게 측정

- 경주대회(Race test)

공기역학적으로 제작된 모형 자동차를 주행 길이 $20 \mathrm{~m}$ 인 경주 전용 트랙에서 직선가속 주행(Drag race)로 경주 를 벌인다. 최단시간 내에 완주하는 모형차가 우승자로 결정된다. $\mathrm{CO}_{2}$ 모형 경주차의 성능을 알 수 있는 Time trial 경주를 실시한다. 임펄스 장치(Impulse system)는 랩 타임을 0.01 초 정밀도로 측정하여 객관적인 얻을 수 있 다. 다음 그림 9 는 경주대회를 준비 장치를 보여준다.

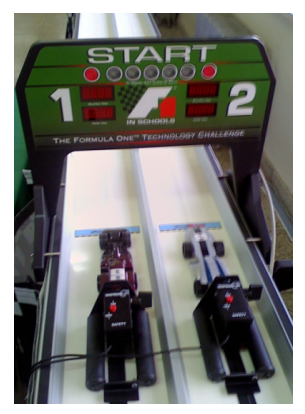

[그림 9] 경주 대회

\section{3. 이론적 배경}

\section{1 공기역학적 설계}

도로에서 차량이 주행하는데 여러 가지 저항력을 받는 다. 이를 주행저항이라 하며 직선 정속 주행 중에는 일부 는 구름저항이며, 일부는 공기역학적 항력이다. 공기역학 적 항력은 약 $65 \sim 80 \mathrm{~km} / \mathrm{h}$ 이상의 속도에서 우세하게 증가하며, 항력 감소의 문제가 중요하게 인식된다. 차량이 다양한 형태와 크기로 만들어지는 공기역학적 항력을 비 교하는데 항력계수 $\left(C_{D}\right)$ 편리하게 사용한다. 공기역학적 항력은 차량의 투영면적, 공기밀도 및 차량 속도의 제곱 에 의해 좌우된다. 공기 항력은 다음 식으로 정의된다[6].

$$
F_{a}=\frac{1}{2} \rho V^{2} C_{D} A
$$

여기서, $\rho$ 는 공기밀도, $A$ 는 전면 투영면적, $V$ 는 차량 속도

식(2)을 정리하면 항력계수는 다음과 같은 형태로 쓸 수 있다.

$$
C_{D}=\frac{F_{a}}{\frac{1}{2} \rho V^{2} A}
$$

\section{2 공기역학적 설계 분석}

학생들이 제작한 $\mathrm{CO}_{2}$ 모형 경주차의 항력 계수를 이 해하는지 알아보기 위하여 학생들이 풍동 시험을 스스로 수행해 보게 하였으며 실험방법은 다음과 같다.

- 실험절차

1) 소형풍동 시험부의 지지대 위에 모형 경주차를 올 려놓는다.

2) 모형 경주차의 밑면에 장착된 아이스크루에 로드 셀 커넥터를 연결한다.

3) 소형 풍동의 전원을 켠다.

4) 풍속 조절기를 서서히 작동시켜 원하는 풍속으로 설정한다.

5) 이때의 원하는 공기 저항력을 측정한다.

6) 전면 투영면적을 측정한다.

먼저 공기 속도를 $52.5 \mathrm{~km} / \mathrm{h}$ 의 고정하고 두 종류의 형상이 다른 $\mathrm{CO}_{2}$ 모형 경주차을 선정하여 풍동에서 공기 저항력을 시험하여 항력계수를 계산 하였다. 첫 번째 형 상은 가공하기 이전의 사각형 모양의 뭉뚝한 재료 상태 
의 모형 경주차이고, 두 번째 형상은 물방울 낙하 형상으 로 유선형화한 $\mathrm{CO}_{2}$ 모형 경주차 이다. 표 6 는 두 종류의 $\mathrm{CO}_{2}$ 모형 경주차 형상에 따른 항력계수를 계산하여 관계 를 비교하면 다음과 같다. 동일한 전면 투영 면적과 동일 한 속도로 차량이 이동 할 경우에 항력계수는 차량의 형 상에 의존하고 높은 항력계수를 갖는 많은 공기 항력을 만든 다는 것을 알 수 있었다. 동시에 $\mathrm{CO}_{2}$ 모형 경주차의 형상 설계에서 공기 항력을 감소하기 위하여 좋은 공기 역학적 모양이 유선형 형상 모양임을 보여주었다.

그림 10 은 표 6 에서 사용한 동일한 서로 다른 2 가지 항력계수에서 차량속도에 대한 공기역학적 항력의 관계 를 보여준다. 모형 경주차의 속도가 빠를수록 공기 항력 이증가하며 약 $50 \mathrm{~km} / \mathrm{h}$ 에서 우세하게 증가하고 있다. 즉 차량의 속도가 고속으로 증가함에 따라 유선형의 형 상이 아주 중요함을 알 수 있다.

[표 6] 항력계수 $\left(C_{D}\right)$ 계산 결과

\begin{tabular}{|c|c|c|c|}
\hline $\begin{array}{c}\text { 차량 } \\
\text { 형상 }\end{array}$ & $\begin{array}{c}\text { 전면투영 } \\
\text { 면적 }\left(m^{2}\right)\end{array}$ & $\begin{array}{c}\text { 공기 } \\
\text { 항력 }(g)\end{array}$ & $\begin{array}{c}\text { 항력 } \\
\text { 계수 }\left(C_{D}\right)\end{array}$ \\
\hline 사각형 & 0.002 & 23 & 0.16 \\
\hline 유선형 & 0.002 & 37 & 0.12 \\
\hline
\end{tabular}

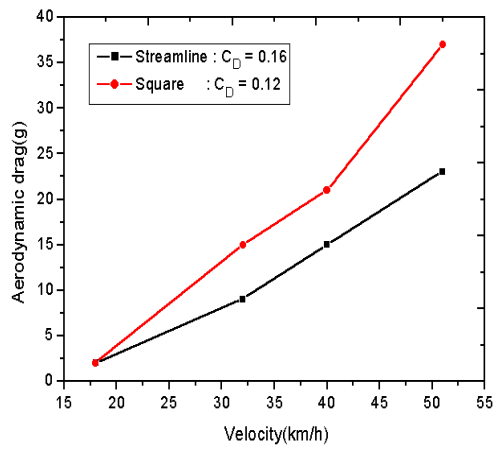

[그림 10] 차량 속도와 항력과의 관계

[표 7] 경주결과

\begin{tabular}{|c|c|c|c|c|}
\hline 팀명 & 랩타임(s) & $\begin{array}{c}\text { 평균속도 } \\
(\mathrm{m} / \mathrm{s})\end{array}$ & 무게(g) & 항력 $(\mathrm{g})$ \\
\hline $\mathrm{A}$ & 1.2 & 16.67 & 55 & 21 \\
\hline $\mathrm{B}$ & 1.24 & 16.13 & 55 & 22 \\
\hline $\mathrm{C}$ & 0.98 & 20.24 & 55 & 19 \\
\hline $\mathrm{D}$ & 1.01 & 19.80 & 55 & 20 \\
\hline $\mathrm{E}$ & 1.06 & 18.96 & 55 & 20 \\
\hline
\end{tabular}

5 개 팀으로 구성된 학생들이 제작한 모형 경주차를 이
용하여 동일한 공기속도 $55 \mathrm{~km} / \mathrm{h}$ 에서 경주 랩타임, 무 게, 항력을 측정하여 표 7에 나타내었다. 여기서 무게는 모두 같다. 동일한 무게에서 $\mathrm{C}$ 팀은 공기항력이 가장 작 으며 가장 짧은 랩타임을 기록하였다. 따라서 항력이 주 요하게 영향을 미치는 요소임을 알 수 있다.

또한 $\mathrm{CO}_{2}$ 모형 경주차 전방에 연기 발생장치인 스모 크 갈퀴를 설치하여 사각형 모양의 뭉뚝한 재료 상태의 모형 경주차 주위에서 유동의 유선을 살펴보는 실험을 하였다. 사각형 모양의 뭉뚝한 모야의 전방부분에서 정체 하여 위와 아래로 분리된 유선으로 표면에 붙어 층류로 이어지다 후방에서 박리되어 난류로 바뀐다.

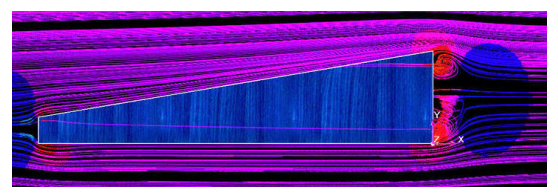

[그림 11] 사각형 모양의 뭉뚝한 $\mathrm{CO}_{2}$ 모형 경주차의 유동

\section{$3.3 \mathrm{CO}_{2}$ 모형 경주차에 작용하는 힘 해석}

$\mathrm{CO}_{2}$ 모형 경주차에서 $\mathrm{CO}_{2}$ 가스의 분출하면서 발생한 추력으로 전용트랙을 달리 때 학생들은 어떠한 종류의 힘이 작용하는지 알기 위하여 자유 물체도를 작성하였다. 그림 12 는 학생들이 수행한 자유물체도 결과이다. 즉 공 기역학적 항력을 극복하기 위하여 저항, 그리고 타이어와 지면 사이 마찰을 극복하는 저항으로 사용된다. 그리고 중력과 양력이 작용한다.

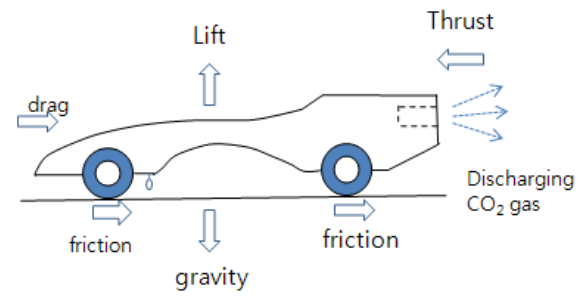

[그림 12] $\mathrm{CO}_{2}$ 모형 경주차에 작용하는 힘

그리고 학생들은 차축과 차축 베어링으로 사용되는 빨 대, 줄과 스크루아이 홀, 바퀴와 본체, 바퀴와 지면 등 여러 곳에서 다양하게 마찰이 발생한다고 분석하였다. 이때의 구름 저항은 다음과 [식 4]와 같은 관계식으로 도출하였다.

$$
F_{r}=\mu_{r} W
$$

여기에서 $\mu_{r}$ 는 구름 마찰계수, $W$ 는 무게 


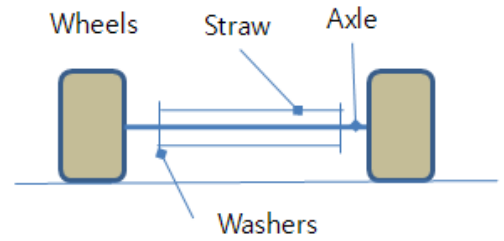

[그림 13] 차축의 마찰 요소

\section{4. 연구방법}

\section{1 설문지 문항}

설문지 문항은 $\mathrm{CO}_{2}$ 모형 경주차 제작에 참여한 학생 에게 차량 공기역학의 공학설계에 대한 학습효과에 따른 공학설계 능력 향상, 공학설계 수업의 만족도를 파악하기 위하여 설문지를 개발하였다. 평가 문항은 미국 공학 평 가 기관인 $\mathrm{ABET}$ 및 한국공학인증원에서 발표한 공학도 가 요구되는 능력 중에서 공학설계 수업에 따른 중요하 다고 판단되는 공학설계 능력 5 개 문항, 공학설계 수업의 만족도 4 개 문항 총 9 개 문항으로 구성하였다[3,4]. 표 8 은 설문지 평가 문항은 공학설계 능력과 만족도로 구성 된 내용을 보여준다. Likert 5 단계 척도를 근거로 학생들 이 직접 설문지 문항을 평가하도록 하였으며, 최고 5 점에 서 최저 1점을 사용하였다.

[표 8] 설문지 평가 문항 내용

\begin{tabular}{|c|l|}
\hline 영역 & \multicolumn{1}{|c|}{ 내 용 } \\
\hline \multirow{5}{*}{ 공학 } & 자료를 이해하고 분석하는 능력 \\
\cline { 2 - 3 } 설계 & 요구된 필요조건에 맞춰 요소, 공정, 시스템을 \\
\cline { 2 - 2 } & 요구된 필용죠려ㄱㅓㅓㄴㅇㅔ 맞춰 제작하는 능력 \\
\cline { 2 - 2 } & 전공지식을 창의적으로 활용하는 능력 \\
\cline { 2 - 2 } & 시험을 계획하고 수행하는 능력 \\
\hline \multirow{5}{*}{ 만족도 } & 공학설계 수업 방법 \\
\cline { 2 - 2 } & 공학설계 수업 과정 \\
\cline { 2 - 2 } & 공학설계를 통한 공기역학 이해 \\
\cline { 2 - 2 } & 공학설계에 대한 중요성 인식 \\
\hline
\end{tabular}

\section{2 자료 분석}

자료 분석은 학기 초와 학기말에 두 번에 걸쳐 실시된 설문 조사 결과를 활용하였다. 학생들의 공학설계 능력 향상과 수업 만족도 차이를 비교하였다. 수집된 자료는 SPSS version 10.0 프로그램을 사용하여 분석하였다. 통 계량 처리는 평균, 표준편차, $\mathrm{t}$ 검증, 유의 수준은 $p<0.05$ 로 하였다.

\section{3 연구 결과}

설문조사에 참여한 학생은 총 39 명이며 모두 자동차 계열의 모터스포츠전공 학생이었다. 공학설계 능력 항목 을 묻는 5 개 문항에 대하여 학기초 평균점수가 2.68 에서 학기말 4.28로 높은 점수를 얻었으며, 1.6 점수 차가 있었 다. 학기 초에 비해 학기말에 더 높은 점수를 보여 공학 설계의 수업이 공학설계 능력 향상에 유의미한 차이를 보였다.

각 문항에 대한 구체적인 내용의 설문조사 결과는 표 9에 나타내었으며, $\mathrm{t}$ 검증 결과 공학설계 능력과 수업 만 족도에 학기 초에 비해 학기말에 이르러 높게 평가하였 으며 상당한 차이를 보이고 있다.

[표 9] 공학설계 능력 변화 및 수업 만족도 분석

\begin{tabular}{|c|c|c|c|c|c|c|c|}
\hline $\begin{array}{l}\text { 영 } \\
\text { 역 }\end{array}$ & 항목 & 학기 & $\mathrm{N}$ & 평균 & $\begin{array}{c}\text { 표준편 } \\
\text { 차 }\end{array}$ & $\begin{array}{c}\text { 평균 } \\
\text { 차 }\end{array}$ & $\mathrm{t}$ \\
\hline \multirow{10}{*}{$\begin{array}{l}\text { 공 } \\
\text { 학 } \\
\text { 설 } \\
\text { 계 }\end{array}$} & \multirow{2}{*}{$\begin{array}{l}\text { 자료 } \\
\text { 분석 } \\
\text { 능력 }\end{array}$} & 초 & 37 & 2.89 & 0.55 & \multirow{2}{*}{1.23} & \multirow{2}{*}{6.77} \\
\hline & & 말 & 37 & 4.13 & 0.85 & & \\
\hline & \multirow{2}{*}{$\begin{array}{l}\text { 공정 } \\
\text { 설계 } \\
\text { 능력 }\end{array}$} & 초 & 37 & 2.63 & 0.48 & \multirow{2}{*}{1.68} & \multirow{2}{*}{14.04} \\
\hline & & 말 & 37 & 4.31 & 0.66 & & \\
\hline & 제작 & 초 & 37 & 2.60 & 0.49 & \multirow{2}{*}{1.71} & \multirow{2}{*}{14.40} \\
\hline & 능력 & 말 & 37 & 4.32 & 0.67 & & \\
\hline & 창의 & 초 & 37 & 2.55 & 0.50 & \multirow{2}{*}{1.92} & \multirow{2}{*}{16.62} \\
\hline & 능력 & 말 & 37 & 4.47 & 0.55 & & \\
\hline & \multirow{2}{*}{$\begin{array}{l}\text { 시험 } \\
\text { 수행 } \\
\text { 능력 }\end{array}$} & 초 & 37 & 2.76 & 0.63 & \multirow{2}{*}{1.44} & \multirow{2}{*}{9.68} \\
\hline & & 말 & 37 & 4.2 & 0.76 & & \\
\hline \multirow{8}{*}{$\begin{array}{l}\text { 만 } \\
\text { 종 }\end{array}$} & 수업 & 초 & 37 & 3.2 & 0.55 & \multirow{2}{*}{1.23} & \multirow{2}{*}{7.63} \\
\hline & 방법 & 말 & 37 & 4.5 & 0.64 & & \\
\hline & 수업 & 초 & 37 & 3.42 & 0.68 & \multirow{2}{*}{1.18} & \multirow{2}{*}{10.00} \\
\hline & 과정 & 말 & 37 & 4.6 & 0.6 & & \\
\hline & 공기 & 초 & 37 & 3.36 & 0.58 & \multirow{2}{*}{1.47} & \multirow{2}{*}{15.05} \\
\hline & 역학 & 말 & 37 & 4.84 & 0.39 & & \\
\hline & 공학 & 초 & 37 & 3.31 & 0.47 & \multirow{2}{*}{1.47} & \multirow{2}{*}{17.95} \\
\hline & 설계 & 말 & 37 & 4.78 & 0.39 & & \\
\hline
\end{tabular}

이 결과에서 공학설계 능력 항목 중에서 학생들이 학 기말에 창의성 능력에서 가장 높은 점수를 얻었으며 창 의력 능력이 높은 성취도를 보였다. 학생들의 차량 공기 역학 수업에 공학설계 프로젝트를 통합한 교수 만족도 
항목을 묻는 4문항에 대하여 학기초 평균 점수 3.32에서 학기말 평균점수 4.68 로 높은 점수를 얻었으며, 1.3 점수 차가 이었다. 교수 만족도 설문 항목 중에서 공기역학의 이해, 공학설계 중요성 인식에 대한 학기말 평균 점수가 각각 4.84와 4.78을 보여 상당히 높은 만족도를 보였다. 즉 학생들이 공학설계 프로젝트를 통한 공학 교육의 개 선 노력에 상당히 높은 관심도를 보여주었다.

\section{5. 결론}

본 연구는 $\mathrm{A}$ 대학 모터스포츠 전공의 차량 공기역학 수업에 공학설계 프로젝트인 $\mathrm{CO}_{2}$ 모형 경주차 제작을 실 시하였다. 그리고 학생들의 수업 개선 효과를 파악하기 위하여 설문지를 개발하고, 분석결과를 토대로 공학설계 능력 향상과 수업 만족도를 확인 하였다. 이 연구의 구체 적인 연구 결과를 통하여 얻는 결론은 다음과 같다.

차량 공기역학에 포함된 공학설계 업무를 규명하고 교 과목에 수행되는 $\mathrm{CO}_{2}$ 모형 경주차 공학 설계 프로젝트 교육을 하기에 효율적인 수업 전략을 구안하고 효과적인 전체 시행과정을 제시하고 수업도구와 학습 자료의 핵심 내용을 제공하였다. 교수는 많은 시간과 노력이 수반되는 어려움이 있음에도 불구하고 설계 노트 준비 및 제공, 공 학설계를 수행하기 위해서 필요한 시설, 공구, 준비물 등 상세하게 개발하였다. 공학설계 시행 과정은 학생들이 가 장 빠른 $\mathrm{CO}_{2}$ 모형 경주차 설계목표로 전공지식을 창의력 을 활용하여 규정에 만족하도록 주어진 부품과 재료를 이용하여 가공하고 조립하여 제작하도록 설계노트를 개 발하여 제공하였다. 완성된 $\mathrm{CO}_{2}$ 모형 경주차의 풍동에서 공기 항력을 측정하여 항력계수를 계산하고 가속 경주를 통하여 성능을 분석하는 경험을 제공하였다. 그리고 학생 들은 최종 $\mathrm{CO}_{2}$ 모형 경주차 작품을 완성하였다.

공학설계 할용으로 공학도가 갖추어 기본 능력과 만족 도에 대하여 설문지를 통하여 확인된 결과에 많은 시사 점을 주고 있다. 학생들이 학기초에 비해 학기말에 이르 러 공학설계의 능력 향상과 만족도 높게 평가한 것은 공 학설계 수업의 실시가 충분한 효과를 보였다는 의미를 알 수 있었다. 학생들의 공학설계 능력 항목 중에서 다른 기본 능력보다 창의력이 더 높은 점수를 받아서 구체적 으로 효과가 있음이 확인되었다. 그리고 학생들의 수업에 대한 흥미 유발되어 학기초에 비해 학기말에 대한 만족 도 점수의 증가는 바람직한 수업방식으로 인식되었다.

$\mathrm{CO}_{2}$ 모형 경주차 항력계수는 사각형 모양일 때 보다 유선형 모양일 때 최소가 되었다. 항력계수는 차량의 기 하학적 형상에 따라 결정되며 최적의 "눈물방물 낙하"
모양(“유선형화”된 원통)이 항력이 최소화 할 수 있는 형 태임을 알 수 있었다. 학생들은 $\mathrm{CO}_{2}$ 모형 경주차 형상에 항력계수를 낮추는 유선형 모양을 적용하여 작품을 제작 하였다. 그리고 풍동 실험에서 $\mathrm{CO}_{2}$ 모형 경주차 형상이 사각형 모양을 가진 경우보다 유선형 형태의 모양이 공 기역학적 항력이 감소하였다.

\section{참고문헌}

[1] 주후, "디자인 프로젝트의 적용과 평가:재료역학 수업 의 사례연구”, 공학교육연구, 제6권, 제 1 호, pp.15-21, 2003.

[2] 류지호, 박재희, "F1 in School 프로그램을 이용한 공 학교육 사례연구”, 2008년 한국 자동차 공학회 창립 30주년 기념 학술대회 논문집, pp.1590-1595, 2008.

[3] Brian S. Thompson, "Creative Engineering Design", Okemos Press, 1998.

[4] 송동주, "공학교육의 문제점과 개선방향에 대하여", 공학교육과 기술, 제10권 제2호, pp.85-92, 2003.

[5] 한병기, 임현준, 지해성, “공학교육에서의 디자인 및 창의적 설계교육-홍익대학교의 사례를 중심으로”, 대 한기계학회 2006년 춘계학술대회 강연 및 논문 초록 집, pp.3219-3223, 2006.

[6] 송윤섭, “자동차 설계”,청문각, 2004.

\section{장 현 탁(Hyun-Tak Jang)}

[정회원]

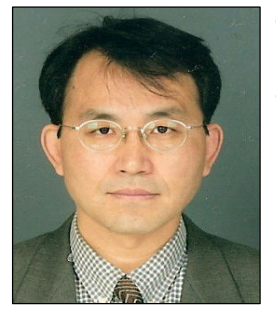

- 1994년 2월 : 충남대학교 대학원 기계설계공학과 (석사)

- 2005년 2월 : 충남대학교 대학원 기계설계공학과 (박사수료)

- 1994년 1월 1997년 2월 : 고 등기술연구원 선임연구원

- 1997년 3월 현재 : 아주자동 차대학 모터스포츠전공 교수

<관심분야>

경주차 공학, 자동차공학 